\title{
Physicians and healing personnel in the works of Flavius Josephus
}

\author{
By Samuel S. Kottek
}

In the preface to his small book: «Die Medizin im Flavius Josephus», ${ }^{1}$ Neuburger stressed the fact that Medicine in the Bible and Talmud ${ }^{2}$ had been studied by several authors, but little reference had been made to the works of Josephus.

Born in Jerusalem in $37 \mathrm{AD}$, Josephus was still alive at the beginning of the second century. At the age of 26 Josephus travelled to Rome and was very much impressed by its power and splendor. At the outbreak of the Jewish revolt (66 AD), he was appointed commander of the army in Galilee, and surrendered to Vespasian after the decisive fall of Jotapata (67 AD). Josephus was shrewd enough to gain the favors of the Roman general after which he accompanied Titus in his campaign which ended with the fall of Jerusalem. He eventually settled in Rome, where he was granted Roman citizenship. Most of the Jews despised him; they tried several times to bring severe accusations against him, but Josephus successfully secured the protection of three successive Roman emperors: Vespasian, Titus and Domitian.

The ambivalence of his stand between Rome and Jerusalem on the one hand, and between history and theology on the other, and the fact that he lived in one of the most troubled periods in Jewish history, should be kept in mind.

Josephus wrote four works: "The Jewish War", a war in which he had been heavily involved, thereby making things, historically speaking, easier on the one hand, and more difficult on the other. "Jewish Antiquities", Josephus' version of the biblical narrative, is obviously aimed at Gentile readers, as was the Septuagint version of the Bible, which he apparently used more frequently than the Hebrew text. In "Against Apion", Josephus appears as a Jew uncompromisingly committed to his correligionists. "The Life", his autobiography, is a defense against the attacks of his old enemy Justus of Tiberias.

In this paper we intend to review Josepus' statements on physicians and medical personnel - occasional or professional. In a first part we shall make reference to his account of the history of the Jews as depicted in the Bible, and in a second part, we shall deal with the post-biblical period. 
We are aware of the fact that there is in this study no attempt to provide the reader with complete information on the historical background regarding the citations used, neither could we treat all the philological problems in depth.

In Neuburger's work, the chapter on Physicians and Healing Personnel covers only two and a half pages.

Basically, it may be contended that there was little to add to what that trained and renowned historian had collected. We tried, nevertheless, to compare Josephus' statements with the Hebrew Bible, with the Septuagint and, whenever possible, with other Jewish sources such as apocryphal and pseudepigraphical works and also with the Talmud and Midrash. ${ }^{2}$

Whenever similarities with Josephus' statements can be found in other sources, it may be surmised that there was some kind of a medical tradition standing behind Josephus' text.

\section{Physicians in the Bible ${ }^{3}$}

The first quotation in the Bible on healing can be found in Ex.21, 19. In Josephus (Ant. IV, 277) the case is presented as follows: "If he recover and hath spent much on his doctoring, the other shall pay all that he hath expended during the time of his confinement to his couch and all that he hath given to the physicians."

The Hebrew text is rendered by the King James Version (KJV) as follows: ... "Only he shall pay for the loss of his time, and shall cause him to be thoroughly healed." That means, that if anyone has wounded a fellowman, he must pay the price of healing.

The biblical expression 'Ve-Rapo-Yerape', rendered by the KJV as "he shall (cause him) to be thoroughly healed", does not make a clear reference to physicians, but the Talmud, in the name of the school of R.Ismael, interprets this statement as a granting, a permission for the practice of medicine [B.T., Berakhot, fol. 60 a).

The Septuagint has: "Plen tès argeias autou apotisei, kai ta iatreia". The term Iatreia means 'healing', and thence, the cost of healing. But to the translators of the Septuagint it was already understood as 'medical care', which of course implies physicians. It was thus quite appropriate for Josephus to translate "all he hath given to the physicians", as it was for the disciples of Rabbi Ishmael (2nd cent.) in their talmudic statement. But the 
Sages of the Talmud consider medicine to be a social necessity, whereas theologically speaking the Lord remains the Great Physician: "It is not the sphere [the ways] of man to heal, but it has been [established by common] usage" (ibid.)

Interestingly enough, this talmudic 'permission' to practise medicine has been questioned later on by medieval scholars. The biblical commentator Abraham Ibn Ezra, although trained to some extent, so it seems, in the art of medicine, thought that the biblical permission should be limited to similar cases: wounds or injuries, or external diseases only. About half a century later, the physician and scholar Nahmanides expressed the idea that although permission was given to the physician to cure, the righteous should be protected by the Lord's blessings (Leibowitz, 1983). Whenever diseased, they should scrutinize their behavior, but it is not evident that they have the right to seek the aid of a physician. This reminds us the case of King Asa, who was rebuked for having sought the help of the physicians instead of praying to the Lord [II Chron. 16, 12].

At any rate, it is obvious that professional physicians practised in Judaea in Josephus' times. In the Christian Gospels, it appears that physicians were commonly sought for the diseased. We cite [Matt.9, 12]: (said Jesus to the Pharisees): "They that be whole need not a physician, but they that are sick." (See also Mark 2, 17 and Luke 5, 31). ${ }^{4}$

In the Hebrew Bible, the word used for physician or healer-Rophe - appears for the first time in GEN.50, 2: "And the "physicians"5 embalmed Israel ..." These specialists of embalming are cited as "servants" of Joseph: "And Joseph commanded his servants the physicians to embalm his father" (ibid). This is not mentioned by Josephus, who simply states that Jacob died and Joseph brought his dead body to Hebron.

The Septuagint translates 'Ropheim' by 'Entaphiastai', the embalmers. We cite: "And Joseph commanded his servants the embalmers to embalm his father; and the embalmers embalmed Israel." The Greek word used for 'servants' is $\pi \alpha \tilde{\iota} \varsigma$ (PAIS), which means child, and young servant or slave as well.

It thus appears that Josephus wrote in accordance with the Septuagint where the words "Physicians" is not mentioned. He does not even mention the embalming, with which his hellenistic-Roman readers were most probably unfamiliar. Those who did know about this custom, were culturally opposed to it. ${ }^{6}$

But if we come back to the Hebrew Bible, we might ask again why the 
term Rophē has been used in relationship with embalming. Ritter (in Preuss 1911, p. 18, n. 9) thinks that Joseph wanted his father to be embalmed, not by the professional embalmers, but by his own "physicians"; there might have been good reasons for such a choice. ${ }^{7}$

Preuss himself says that the term Rophē was used because there was no more specific term available for a practice that was strange to the Hebrews.

In fact, the etymology of Rophē has given rise to discussion. It might be derived from Rapha (ר), to alleviate, to ease, to relieve, or from a root meaning to improve, to mend. ${ }^{8}$

So the word Rophē could possibly have been chosen in the sense of repairing, of putting in shape, of adjusting a corpse.

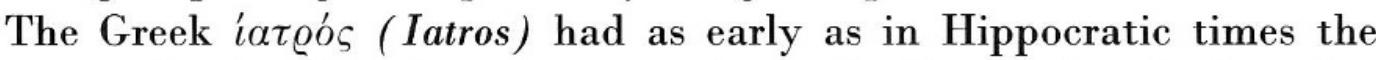
meaning of healer. But this term is usually applied in Greek to healers that command some basic medical theory, whereas the Hebrew Rophē seems to have had originally a much broader sense.

The quotations of Josephus on physicians have not always a parallel in Scriptures. Let us give a few examples.

\section{Abimelekh}

Abimelekh, "being enamoured of Sarra ... was restrained from his lustful intent by a grievous disease inflicted upon him by God. The physicians had already despaired of his life ..." [Ant. I, 208].

In Scriptures it says: "But God came to Abimelech in a dream by night, and said to him, Behold, thou art but a dead man, for the woman wich thou hast taken; for she is a man's wife" [Gen.20,3]. And later, we read: "So Abraham prayed unto God: and God healed Abimelech and his wife, and his maidservants; and they bare children." (ibid., 17)

There is seemingly a confusion, or a transfer of what happened to Pharaoh in similar conditions [Gen. 12, 17]: "And the Lord plagued Pharaoh and his house with great plagues because of Sarai Abram's wife." This could account for the alleged "grievous disease". This episode is realted briefly by Josephus as "a distemper", but he adds unexpectedly political disturbances ("a sedition against his government") ${ }^{9}$

We might recall here that the text called "A Genesis Apocryphon"10, discovered in one of the Qumran scrolls, also develops a lengthy description of the epidemics that befell Pharaoh and his household when he took Sarai from her husband. 
Saul

Describing the well-known "melancholy" of King Saul, Josephus uses a language which differs from the Scriptural sources. He says:

"The physicians could devise no other remedy save to order search to be made for one with power to charm away spirits and to play upon the harp, and, whensoever the evil spirits should assail and torment Saul, to have him stand over the King and strike the strings and chant his songs." [Ant. VI, 166].

In the Bible [I Sam.16, 15-16] we read: "And Saul's servants said unto him, Behold now, an evil spirit from God troubleth thee . Let our Lord now command thy servants ... to seek out a man, who is a cunning player on an harp ..." The text of the LXX is quite similar. The Hebrew Eved (Avdei) means nothing more than servants. ${ }^{11}$ Were there healers amongst these servants? Possibly, but to Josephus' readers it was a necessity, whereas in the biblical text there was neither need nor interest in recording the presence of physicians in such a context.

Therapy by music was in use since antiquity. Music was part of the mathematical sciences in Babylon. The Pythagoreans apparently brought these ideas to the Greeks. Music had an influence on the gods, so they thought, and on man's soul as well. Recording a therapeutical procedure, Josephus quite naturally introduces physicians in his narrative.

\section{Hezekiah}

Josephus' version of King Hezekiah's disease is much more detailed than that of the Hebrew Bible. We read: "He (Hezekiah) was smitten by a severe illness, and all hope for him was given up by the physicians, nor did his friends have any expectation of a change for the better in his condition." [Ant. X, 25].

In the Hebrew Bible, we are told that King Hezekiah "was sick unto death" [II Kings, 20, 1] or, according to a second version: "In those days Hezekiah was sick to the death" [II Chron. 32, 24]. The third source, although giving an indication on the treatment applied by the prophet, makes no reference to physicians [Isaiah, 38, 1, 21].

An interesting point is added by Josephus, apparently without a parallel in the Hebrew Bible. he states that the King was in a state of "melancholy", reflecting that he was going to die childless, and therefore prayed to the Lord that he should grant him some more years of life until he had a child. 
This assertion seems to be based on a verse of a special prayer (literally "letter") composed by King Hezekiah after his recovery (Isaiah, 38, 9-20). This verse was translated differently by the Septuagint than by all the other versions. Let us consider this verse (Is. 38, 19):

$K J V$ : "The living, the living, he shall praise thee, as I (do) this day: the father to the children shall make known thy truth."

$L X X$ : "The living shall bless thee, as I also (do): for from this day shall I beget children, who shall declare thy righteousness."

The Masoretic punctuation of the Hebrew text is in accordance with the first translation. So once again, Josephus seems to have been inspired by the Septuagint version of the Bible.

The Talmud also records the story, although somewhat differently [Berakhot, fol $10 \mathrm{a}$ ]: Hezekiah asks Isaiah why he has been doomed to death. He answers: Because you did not bother to have children. The King answers that he has foreseen that his children would be worthless. But the prophet rebukes him saying that he should fulfill his duty, leaving the rest to God. ${ }^{12}$

Another remark could be added: although Josephus relates the sign (miracle) performed by the Prophet (the sun regressed ten degrees), he does not recall the treatment indicated in Is. 28, 21 ( a lump of figs upon the boil) ${ }^{13}$ and gives no indication on the nature of the 'grave distemper'.

\section{King Solomon, his knowledge of medicine and magic}

According to the Hebrew Bible, King Solomon was granted by the Lord, at the very beginning of his reign, "a wise and understanding heart, so that there was none like thee before thee, neither after thee shall any arise like unto thee." [I Kings 3, 12]. Further on, we read: "And Solomon's wisdom excelled the wisdom of all the children of the east country, and all the wisdom of Egpyt; For he was wiser than all men ... and his fame was in all nations round about." (ibid.4, 30-31). The text even stresses Solomon's knowledge in botany and zoology. But medicine is not cited.

Josephus here echoes Midrashic writings and pseudepigraphic sources, when he credits King Solomon with a thorough knowledge in medicine, particularly stressing magic cures: "And God granted him knowledge of the art used against demons for the benefit and healing of men. He also composed incantations by which illnesses are relieved, and left behind forms of exorcisms with those possessed by demons drive them out, never to 
return." 14 [Ant.XIII, 45]. Josephus then describes a scene of exorcism conducted in his presence, before Vespasian, by a certain Eleazar, who was possibly an Essene.

Statements concerning King Solomon's magical curing methods pervaded the whole period of the Middle Ages, most probably through Josephus and through pseudepigraphic writings.

The "Book of Jubilees" $(10,17)$ and the "Book of Noah" (Jellinek, 1938) conveyed the tradition according to which the "Book of Medicines" was handed over to King Solomon by the successive heirs of Shem, the son of Noah, to whom it was dictated by Angels. ${ }^{15}$

The Talmud takes an ambivalent stand towards magical practices. On the one hand, the Rabbis put a ban on those who used apocryphal works or used incantations to cure diseases (Sanhedrin, XI, 1). On the other hand, the legend of the seal of Solomon appears in the Tractate Gittin, fol. 68 ab. ${ }^{16}$

The Mishna also records that King Hezekiah-cited above-was praised by the Sages for having banned the "Book of Medicines" (Sefer Refuoth). The name of King Solomon does not appear in this text, but has been associated with this anonymous work. Maimonides (Perush Hamishnayoth, on Pesahim 56a) interprets this occultation in tow different ways. Firstly, the reason could have been that this book contained means of treatment prohibited by the law such as astrological or magical means that one may study but not apply. The second reason could be that this book was an antidotarium containing formulae of poisonous drugs and their antidotes. As people began to use such prohibited or noxious means, the book had to be banned.

The interesting point in this chapter is, that the Hebrew Bible does not include medicine when detailing King Solomon's wisdom, whereas midrashic and pseudepigraphic works include it, just as Josephus did. They were widely referred to during centuries, through authors such as Origenes, Suidas, Glycas a. o. ${ }^{17}$

\section{Prophets}

The numerous wonder-cures that appear in the Christian Gospels are prefigured in the (less-numerous) ones performed by the Biblical prophets. 


\section{Elijah}

The resuscitation of the child of the widow of Sarepta after Elijah's intervention is recorded by Josephus in accordance with the Bible. ${ }^{18}$ It says: The child fell sick, "and his sickness was so sore, that there was no breath left in him". Elijah brings him upon his bed, than prays to the Lord, and then "stretched himself ${ }^{19}$ upon the child three times, and cried unto the Lord"... Then "the soul of the child came into him again, and he revived." [I Kings, $17,17-22]$

Josephus does not mention the prophet's stretching himself over the child, but only his prayer. On the other hand, he offers an explanation of the Lord's intervention: because He wished "to spare the prophet from seeming to have come to her for the purpose of harming her, ${ }^{20}$ beyond all expectation brought the child back to life." [Ant. VIII, 327].

\section{Elisha}

Josephus does not recall the parallel miraculous cure of the son of the Sunamite woman [II Kings, 4, 29-37]. ${ }^{21}$

But his "cure' of the spoiled spring of Jericho is recorded in the "Wars of the Jews". In the Bible, we read: "And he said, Bring me a new cruse, and put salt therein. And they brought it to him. And he went forth upon the spring of the waters, and cast the salt in there, and said, Thus saith the Lord, I have healed these waters ..." [II Kings, 2, 20-21].

Josephus explains: "As a reward for kind hospitality, he caused the waters of a well near Jericho to become pure and healthy." He states further: "This spring originally not only blighted the fruits of the earth and of trees, but also caused women to miscarry ... until it was reclaimed and converted into a most salubrious and fertilizing source ..." 22 [Bell. Jud. IV, 460].

The miracle of the revival of the dead man that touched the bones of Elisah is briefly recorded by Josephus [Ant. IX, 183] in the same words as in the Biblical narrative [II Kings 13, 21].

\section{Midwives}

In the Hebrew Bible, we read: "And the King of Egypt spoke to the Hebrew midwives, of which the name of the one was Shiphrah and the name of the other Puah. And he said, When ye do the office of a midwife to the Hebrew 
women and see them upon the stools; if it be a son, then ye shall kill him, but if it be a daughter, then she shall live" [Exod.1, 15-16].

The Septuagint is slightly, but perhaps significantly different in its rendering of the Hebrew text:

"And the King of the Egyptians spoke to the midwives of the Hebrews; the name of the one was Sepphora and the name of the second Phua."

The Masoretic punctuation of the Hebrew Bible allows only one translation, adopted by all the other versions: "the Hebrew midwives" ( $\mathrm{Ha}$ Meyaledoth Ha-Ivrioth). In saying "the midwives of the Hebrews", the LXX hinted that they could possibly have been of a foreign origin. At any rate, this is exactly what Josephus openly states.

He first states that "a sacred scribe" informed the Egyptian king that a saviour was about to be born among the Israelites, and therefore he decided to throw the male children into the river.

Josephus then adds that the king "ordered ... that the labours of Hebrew women with child should be observed and watch kept for their delivery by the Egyptian midwives: for this office was, by his orders, to be performed by women who, as compatriots of the King, were not likely to transgress his will." [Ant. 2, 206-297].

The Targum of Jonathan ben Uziel (Targum Jonathan) presents the story of tow Egyptian magi, named Jannes and Jambres, who made the prediction to Pharaoh which is recalled by Josephus. The Midrash [Exod. Rabba, 1, 22] tells a similar story. ${ }^{23}$

But the reference to Egyptian midwives appears in none of the known Jewish sources. On the contrary, the Talmud [T. Bab. Sota fol.11b], Midrash [Exod. Rab.1, 17] and Targum Jonathan, identify these two midwives (Shifrah and Puah) as Jokhebed (Moses' mother) and Miriam (Moses' sister) or Elisheva (Aaron's wife).

It is not clear whether here Josephus was in agreement with other exegetes. Perhaps there is an indication in that direction in the slight change in the version of the Septuagint noted above.

As a matter of fact, the Biblical text could seem-to Josephus' readers - either incredible (who would expect Jewish midwives to perform such deeds) - or purely homiletical (to enhance the virtues of members of Moses' family). Therefore he chose a version that looked more "historical". Perhaps he also thought that the statement saying that the Hebrew women "are lively, and are delivered ere the midwives come in unto them", would not have been taken for granted by his readers. 


\section{An omission}

We have already noted that Josephus does not mention the embalming of $\mathrm{Jacob}^{24}$, where the noun Rophe appears for the first time in the Hebrew Bible.

Another omission is related to the disease of King Asa. We read in II Chron. 16, 12: "And Asa in the thirty and ninth year of his reign was diseased in his feet ... yet in his disease he sought not to the Lord, but to the physicians." [see also I Kings, 15, 23] The Talmud (Sota, fol. 10 a) interprets the disease as having been a case of Podagra (gout). The Midrash does not elaborate on Asa's disease. As for Josephus, he does not mention it at all [see Ant. VIII, 314].

\section{Physicians in Post-Biblical times}

In Rengstorf's Concordance, the term Iatros appears nine times in the chapters 14 to 20 of Antiquities, coresponding to that period which, from Josephus' point of view, might be called the 'modern' period.

\section{Herod and his household}

King Herod the Great was King of Judea from 37 BCE until his death in 4 BCE under the sovereignty of the Roman emperors Antony and Octavian (Augustus). Greek medicine had then taken a firm hold in Rome, since the time of Asclepiades of Bithynia (ab. 125 BCE). Knowing Herod's strong links with Rome, it may be safely surmised that at least part of his personal physicians were of the Greek school.

Throughout the narration of Herod's disease ${ }^{25}$ - one could say diseases - there are to be found several references to physicians.

After he had his wife Mariamne put to death, King Herod was seized by fits of melancholy. Then "a pestilential disease" spread, causing the death of many people, amongst them good friends of the King. He himself then fell seriously ill "and all the physicians who surrounded him, partly because the illness did not yield to any of the medicines which they applied ..." abandoned his cure to chance. All this happened as the King was at Samaria [Ant., XV, 246].

Therapeutic abstention and putting one's hopes in the "Natura Medicatrix" 26 was in accordance with the old Coan school, and with the perennial adage "Primum non nocere". 
Towards the end of his life, his desease greatly increased. Nevertheless, the King still had hopes of recovery, therefore he called for physicians and followed their advice ${ }^{27}$ to go to the warm baths of Callirrhoe, across the Jordan river. "There, the physicians deciding to raise the temperature of his whole body with hot oil ${ }^{28}$, he was lowered into a bath full of that liquid ..." [Bell. Jud. I, 657].

Herod's brother, Phasael had been taken into captivity by the Parthians who brought Herod's great rival Antigonus into Judea. Fearing that he sould be put to death by Antigonus, he decided to commit suicide: "As for Phasael - writes Josephus - one must admire his courage, for though he knew that he was marked for slaughter, he did not look upon death as terrible in itself ... and so ... he dashed his head against a rock and removed himself from the world of the living... But some say that when he had incurred this serious wound, Antigonus quietly sent physicians as if to heal it, and had him killed by deadly poisons which they applied to his wound." [Ant. XIV, 367-368]. The parallel narrative in Bell. Jud. is slightly different, stating that Phasael recovered from this stroke, and that $a$ physician (Iatros) subsequently killed him on Antigonus' order by injecting poison into the wound. [Bell. Jud. I, 272]. ${ }^{29}$

Herod's son, Antipater, was also involved in a poisonous plot, directed against his own father. The poison had been secured by a companion of Antipater called Antiphilus, whose mother and sister were subjected to torture. "Both confessed that Antiphilus had brought the box (of poison) from Egypt and asserted that he had procured the drug from another brother, a doctor ${ }^{30}$ in Alexandria." [Bell. Jud. I, 598].

\section{Caligula's physicians}

Caligula (Caius Caesar Augustus) was emperor from 37 to $41 \mathrm{AD}$, that is, in Josephus' lifetime (the latter was born in 37). King Agrippa I, who reigned over Judea, was one of his good friends and was the first Judean ruler upon whom was bestowed a royal title after Herod's death.

The murder of Caligula is described in detail in Josephus' narrative. Cherea and his associates stabbed him as he came out of the theatre. At once, several versions of the assassination circulated among the spectators: "another story had gone about to the effect that though wounded, Gaius was not dead, but alive, and being attended by physicians" [Ant. XIX, 134].

Then there was a kind of panic in the theatre, as people were eager to 
escape the blind search for the murderers. "The person responsible for the spectators being allowed to depart so readily was Alcyon the physician. He had been seized and carried off in order that he might care for some wounded men. He then dispatched those present with him, as if they were to fetch some supplies that he needed to treat the patients, but his real purpose was to remove them from the danger that had overtaken them." [Ant. XIX, 157]. ${ }^{31}$

According to Josephus, King Agrippa I, then in Rome, played a decisive role in securing the rule for Claudius who succeeded Caligula as Emperor. After the murder, Agrippa "attended the corpse of Gaius ... and after dressing it with such materials as were at hand, retired to the bodyguard and announced that Gaius was alive ${ }^{32}$, saying that physicians would be arriving to aid him inasmuch as he was suffering from serious wounds." [Ant. XIX, 237].

\section{Physicians in the Judean army(?)}

The problem of the integration of physicians into the Roman army has been open to debate. Even V. Nutton, who brought some evidence of medical aid in the Roman army, states: "Proof that the Roman army medical services were formally organized is hard to find ..., (p.262). There is nevertheless enough evidence from inscriptions that there were "medici, in the army of the Empire period (around the first century and later). Nutton thinks it plausible that there were capsarii that treated minor wounds, whereas the medici treated the sick. There are also occasional references to a camp doctor (medicus castrorum-or castrensis).

In Hebrew sources, we know of one well-known talmudic statement (Gittin, fol.56 b). During the siege of Jerusalem (69 AD) the scholar Johanan ben Zaccai asks the "Emperor" Vespasian to send to the besieged city "physicians to cure Rabbi Zadoq (who could no longer swallow because he had fasted too long). ${ }^{33}$ This may indicate that the Hebrew garrison had no physician, or - as Preuss surmises - that they had vanished or had been killed. On the other hand, it seems obvious that there were physicians in Vespanian's camp, but we have no information as to whether they belonged to the general's bodyguard, to the legions, or to the camp. Besides, the historicity of the whole incident can hardly be verified by any cross reference. It need not be stressed that it was Titus, not Vespasian, who conquered the Holy City of Jerusalem, but such lack of precision is not infrequent in the Talmud. 
Coming back to Josephus, we find two short statements that might be related to military medicine, but which throw little light on the subject concerning the Judean army.

When Herod won the battle against Antigonus, he was at first opposed fiercely by Judean notables who sent ambassadors to Antonius. But the latter granted the power to Herod and to his brother, which resulted in a massacre of opposing Judeans on the shores of Tyre. "Burial for the dead and medical attention for the wounded ( $(\varrho \alpha v \mu \alpha \tau \iota \alpha \iota \theta \varepsilon \varrho \alpha \pi \varepsilon \iota \alpha \varsigma=$ Traumatiai Therapeias) were granted by Hyrcanus." [Bell. Jud. I, 246].

Josephus himself, before he was taken prisoner by the Romans, bruised his wrist and was conveyed to Capernaum. "My men, hearing of this, and fearing that a worse fate had befallen me, ... returned in the deepest anxiety on my account. I sent for physicians ${ }^{34}$ (Iatrois) and, after receiving their attention, remained there for that day in a feverish condition. At night, under medical advice, I was removed to Taricheae" [The Life, 72, 404].

Medical attention for the wounded could have been provided by some kind of capsarii who possibly existed in Hyrcanus' army, but this is a mere conjecture.

When Josephus "sent for physicians", he does not say "physicians of the army', and these were most probably healing practitioners existing in Capernaum. His removal to the central fortress of Tarichea, where there was stationed a strong garrison, does not necessarily imply that there was any sort of 'medicus castrensis' there.

One could even say that the fact that the commander (Josephus) had no personal physician indicates that the probability that there were medici in the Judean army is very small.

\section{A woman-physician(?)}

One reference to a female physician (Iatrina) appears in Josephus' autobiography. We read: "Josephus, the midwife's son, induced a number of adventurous youths to join him ..." [The Life, 37, 185]. Thackeray thus interprets 'Iatrina' as midwife. Whiston translates: "the son of a female physician" and Neuburger has the same.

Again, it is difficult to decide which translation is more accurate. Moreover, it is known that in the Middle-Ages such an appellation (f.i. in German 'die Arztgattin') was used to designate the wife, or the widow of a physician. 


\section{Surgeons}

The Syrian pretender to the throne, Tryphon, at the time that Simon was chief of the Maccabees, had the young Antiochus slain, whereas he let it be widely known "that Antiochus had died under the hands of the surgeon". [Ant. XIII, 219] ( $ڤ \varsigma \chi \varepsilon \iota \iota \zeta o ́ \mu \varepsilon v o \varsigma ~ \alpha \pi o \theta \alpha v o \iota)$

The 'surgeon' here is clearly the operator - the one who operates with his hands $(\chi \varepsilon \iota \varrho \circ \varsigma)$, whence the term $\chi \varepsilon \iota \varrho o v \varrho \gamma o ́$ (Chirurgos $=$ Surgeon) ${ }^{35}$. It has been suggested that Josephus meant that it was circulated that the young prince died while being bled (foot-note by Marcus).

Circumcision is another surgical operation and appears in Josephus' narrative. Aziates, the king of Adiabene, after some hesitation had the operation performed, when he converted to Judaism: "The king postponed the deed no longer. Withdrawing into another room, he summoned his physician and had the prescribed act performed." [Ant. XX, 46]. Whiston translates: "and sent for a surgeon". But the Greek term used here is 'Iatron' (physician). ${ }^{36}$

In a brief conclusion, we would like to comment that Josephus not infrequently adds to his version of the Bible medical interventions that do not appear in the canonical texts. Although, theologically speaking, disease and healing are in the hands of the Lord, the Bible's approach to medicine, with but one exception, is a positive one. However, there are scant references to physicians, and Josephus added such details that would please his GrecoRoman readers.

Regarding para-medical activity in biblical times, there appears in the biblical narrative no surgeon. Circumcision is performed by the Patriarchs themselves. Interestingly enough, Josephus does not recall the circumcision performed by Moses' wife Zippora on her son [Exod.4, 25]. Midwives are exemplified and extolled. The paramedical activity of priests [Lev.13 and 14] is not mentioned by Josephus [see Ant. III, chap. 11]. ${ }^{37}$

We have shown that several details about physicians or midwives are in accordance with pseudepigraphical or midrashic writings that survived and were conveyed up to our times, others apparently are literary fictions of Josephus.

Now as regards the post-biblical period, we find several interesting descriptions on medical activity more or less contemporary to Josephus. Especially worth mentioning, and in our eyes irritating, is the alleged "medical" involvement in the preparation of poisonous drugs. 
The problem of military medicine and of women-physicians is posed, but not resolved. Surgeons are barely mentioned. Circumcision is, at least in special cases, seen as a medical procedure.

The fact that the Greek word Iatros (physician) is used indifferently for a medical practitioner, i. e. a healer, for a 'surgeon' and for a confectioner of drugs should also be stressed.

Again, our aim in this paper was not to review the medical data scattered in the works of Josephus, but to focus mainly on his records of medical and para-medical activity.

Being aware of the fact that Josephus' writings are one of the very scarce sources in Hebrew antiquity, and comparing them to the earlier canonic Bible and to the later Talmud and Midrash, we have tried to achieve a somewhat claearer picture of his general outlook towards the medical profession.

\section{Notes}

1. M. Neuburger, Die Medizin im Flavius Josephus. Bad Reichenhall, 1919, p.5.

2. For the non-specialized reader, some explanatory notes might be helpful.

Josephus: the translation of Thackeray, Marcus and Feldman and coll. has been used (Loeb Classical Library).

Bible:

- for the Old Testament, the KJV (King James Version) has been used.

- we used also "the Septuagint Version of the Old Testament with an English translation", London 1879.

Targum:

1) Targum Onkelos (Aquilas): Aramaic paraphrase (and at times commentary) of the Bible [dates ab. 2nd cent. A. D.].

2) Targum Jonathan: later Aramaic commentary [ab. 600 AD).

Talmud:

1) Mishna: first redaction of the oral Law, compiled from 2nd cent. BCE to 2-3. cent. AD.

2) Tossefta: additional data not included in the Mishna, but preserved as an appendix.

3) Jerusalem Talmud: development of the Mishna, completed ab. $350 \mathrm{AD}$ in Palestine.

4) Babylonian Talmud: the same, but much more bulky, completed ab. $500 \mathrm{AD}$ in Babylon.

Midrash: homiletic commentaries on the Bible, the redaction of which extended over several centuries. The oldest fragments might have been contemporary with Josephus, other texts have been written until late into the $7-8$ th centuries. 
3. In Rengstorf's Concordance, the term Iatros (physician) is recorded 19 times in the works of Josephus, i. e. twice in the 'War', 15 times in 'Antiquities', and twice in the 'Life'. In the index of Whiston, it does not appear at all.

4. Mark 2, 17: has exactly the same wording, adding: "I came not to call the righteous, but sinners to repentance."

Luke 5, 31-32: exactly parallel to the former.

5. Preuss $(1911$, p. 18) thinks that the Hebrew term 'Rofeim' was used because there was no other available terminology, as embalming was not in use in Hebrew antiquity. The 11th century commentator R.Salomon Itshaqi ('Rashi') stresses that this profession had mainly to do with the preparation of drugs - thence the name "physicians' (Rashi on Gen. 50, 2).

6. Besides, embalming was not usually performed by the Israelites and therefore it could have been interpreted as an example of Egyptian influence on the Hebrews. This could be an additional reason for Josephus not to mention that detail.

7. The Egyptian ceremony of embalming was apparently accompanied by magical procedures which Joseph would perhaps have liked to avoid. Both Herodotus (II, $85 \mathrm{ff}$ ) and Diodorus Siculus describe the ceremony of the "opening of the mouth" when the mummy has gone through the long embalming procedure. But Diodorus $(I, 91)$ also tells us that the "paraschistes" that made the incision in the flank of the corpse to take out the bowels had to flee away, pursued by imprecations and stoned by the "entaphiastai". This was apparently merely symbolic, because the body had been desecrated by the knife, or, more exactly, by the 'Ethiopian stone'. [Encycl. of Rel \& Ethics, J. Hastings ed., vol. IV, 1914, p. 461].

8. According to Genesius, the root $\operatorname{Rape\overline {e}}$ (ר) has essentially the meaning of 'to mend', to repair (flicken, reparieren), according to similar roots in Arabic \& Ethiopian. We need not remind the reader that 'mend' and 'medicine' originate in the same Latin word 'medeor'. The verb 'to mend' is still used in some English and Scottish dialects as meaning to recover, to get better.

9. According to Josephus, the Egyptian priests explained to Pharaoh the reason for these calamities. The Biblical text is very short: Pharaoh summons Abram and bids him to leave the country with his wife; Abram answers nothing at all. But Josephus adds a whole chapter on an alleged encounter between Abram and Egyptian sages; during which theological and scientific matters were discussed, Abram even instructing the Egyptians in mathematics and astronomy. There is no parallel in Talmud or Midrash. [Ant. I, 8, 1-2].

10. 'A Genesis Apocryphon', ed. by Avigad N. and Yadin Y., Jerusalem, Magnes Press, 1956, see pages 20 and 44. See also my paper on 'The Essenes and Medicine', to appear in Clio Medica, Spring 1984.

11. Here again, as in Genesis, physicians appear as a subdivision of servants. Even much later, through the Middle-Ages and even the Renaissance period, those entrusted with healing capacities were not always trained physicians, but sometimes astrologers, magi or quacks, hovering around noblemen or princes.

12. The Midrash credits King Hezekiah of having been 'the first' case of (serious) disease in which there was a recovery, the diseased king having gone through a thorough repentance. Although the prophet Isaiah had foretold his immediate death, the king recovered and lived another fifteen years.

13. Again, the Midrash finds no rational basis for this treatment; on the contrary, it is stated 
that it could have only negative effects on a boil. Therefore the recovery is considered to be a twofold miracle [Yalkut Shimoni, II, 243].

14. Preuss (1911, p. 164, 361) stresses the fact that there is no description of exorcism in the Bible, neither is there actually in the Talmud. He thinks that Josephus told this story to convince his pagan readers that such treatments were not unknown to the Jews. Demonology does appear incidentally in the Talmud, but the descriptions of possession and exorcism are particularly frequent in the Christian gospels, close to the period in which Josephus lived.

15. See Jellinek, Ad.: Beth ha-Midrasch (Sammlung) Jerusalem, Bamberger \& Wahrmann, 1938, 2nd ed., p. XXXII. See also my paper, The Essenes and Medicine, to appear in Clio Medica (Spring 1984).

16. See also on the Seal of Solomon, the Midrash recorded by Jellinek (1938, vol II, pp. 86-87). This ring, later extolled in the 'Claviculae Salomonis', seems to have been known to Josephus. At any rate, he speaks of a ring that the exorciser Eleazar placed before the nose of the possessed man he was treating.

17. Abraham Jagel (cited by I. Reggio, 1836) wrote that an envoy of the King of Armenia visited Pope Clemens VIII (1592-1605) and told him that in his country they were still using books on medicine left by King Solomon. he also remarked that these methods seemed to him more effective than those of Galen and Ibn Sina, then in use in Rome.

18. On Elijah's 'miracles', see the paper of L. Wislicki in the Proceedings of the First International Symposium on Medicine in the Bible, Koroth, Special Issue, Fall 1982, pp. 214-219.

19. The Vulgate translates as does the Targum: "expandit se atque mensus est super puerum",

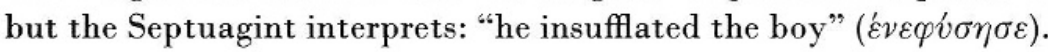

20. The Midrash (Yalkut Shimoni, II, 209) tells the legend according to which the woman accused Elijah of having behaved indecently towards her, then the prophet prays for mercy "in order that they should believe in the resurrection of the dead" and the child comes back to life. Ben Sira $(48,5)$ also praises Elijah "who brings up the agonizing back from death and from the infernal regions on God's will." The word $y$ (Govea) seems to indicate that the child was not really dead, but the verse remains ambiguous.

21. The Midrash does not recall this story either. In the Jerusalem Talmud the Sunamite child's disease is already interpreted as a sun-stroke.

22. Josephus develops this chapter much more than the Biblical text. He prays to the Lord that "the veins of fresh water be opened" and that "a more temperate and fertile air for the current" be secured. Furthermore, "to these prayers Elisha joined proper operations of his hands ... and changed the fountain". Then, Josephus gives an idyllic description of Jericho and its fertility. This lengthy description has a definite Hippocratic flavour (cf. "Airs, Waters and Places").

23. According to the Midrash, Pharaoh ordered that all male children be thrown into the river, Hebrew and Egyptian as well, as the prediction was not clear, whether the saviour of the Jews would be a member of one or the other nation. So on one particular day indicated by the astrologers, all the new-borns of both nations were put to death.

24. It might be surmised that Josephus did not care to recall a specific Egyptian contribution in Jewish history: He was writing for Greco-Roman readers and repeatedly expressed his opposition to Egyptian historians, such as Manetho. 
25. Herod's diseases, as described by Josephus, will be the subject of another paper. A number of authors have ventured to find a common denominator to the diverse symptoms. Let us recall only the names of J. O. Leibowitz, Marcus, Muntner, Naber and A.Schalit.

26. See for instance Hippocrates, Littré T. 5 p. 315 (Epidémies, VI, 5, 1). His follower Aretaeus, who lived in the 1rst century and was as such a contemporary of Josephus, again extolls the role of the 'physis' (De Caus. et Sign ..., I, 13).

27. "So he summoned his physicians and made up his mind to use whatever remedies they might suggest." [Ant. XVII, 172].

28. Regarding warm baths and particularly oil baths, Josephus' contemporary the physician Herodōtos, who practised in Rome, strongly advocated such procedures (cited by Oribasios and Galen). It is said of his master Claudius Agathinos that the suffered "maniac attacks" caused by over-work and lack of sleep and that he was treated by his pupil Archigenes by pouring warm oil on his head. On the effect of warm baths, see also Galen, De Causis Pulsum, lib. II, Cap XIV (Kühn p. 145-147), who cited several times the works of the above-cited 'eclectics'.

29. Josephus makes no comment on this treacherous deed, so completely in opposition to Hippocrates' Oath. Whiston here translates 'Iatros' as surgeon, this kind of medical activity being usually - at least in his times - in the surgeon's hands. This was perhaps also an (unconscious?) attempt at lowering the responsibility of that reprehensible action to the level of a "medical assistant".

30. Whiston translates: "a physician" (Iatroi). Perhaps this word means here no more than "a confectionier of drugs."

31. In this case, a physician apparently uses his privilege to save people exposed to the fury of the soldiers and plays a role pertaining to social welfare or public health in a panic-stricken crowd.

32. The political importance of pretendedly maintaining the lives of absolute rulers until their successions has been secured, need not be emphasized here.

33. But this much cited passage could be an inexact rendering of the Aramaic text, due to the commentary of Rabbi Itshaqi (Rashi, 11th cent.). The word used: Assvata means medicines (see for inst. Baba Metsia fol. $113 \mathrm{~b}$ ), whereas the plural of 'Assia' (physician) is 'Assaia'.

34. Whiston translates: "I therefore sent for the physicians". This may indicate that he believed that there were such medical attendants attached to the army, or to Josephus himself.

35. In the Talmud, the corresponding term is Umman (in Aramaic: Ummana), with the same connotation of manual work. His social stand was, through the Middle-Ages and till the 17th century much below that of the physician.

36. Preuss (p.39, note 10) thinks that the "Physician" was summoned because the operation was to be performed on an adult. During the Maccabeean period, under the cruel rulings edicted by King Antiochus, women-according to Josephus-performed the sacral operation upon their offsprings, for which deed they were strangled. [Ant.XII, 256]. These details do not appear in the parallel text of I Maccabees.

37. But some of the Laws on Leprosy are detailed elsewhere: see Against Apion, Book 1, 31. 


\section{Bibliography}

Africa T.W., Worms and the Death of Kings: a cautionary note on disease and history. Classical Antiquity, 1: 1-17, 1982

Balsdon J.P., The Emperor Gaius. Oxford, Clarendon Press, 1934

Betz O./Haacker K. und Hengel M. (eds.), Josephus Studien ... Otto Michel zum 70. Geburtstag gewidmet. Göttingen (Vandenhoeck u. Ruprecht), 1974 [see paper by O.Betz, pp. 23-44]

Callies H., Zur Stellung der medici im römischen Heer. Med. Hist. J., Bd.3, Heft 1, 1968, pp. 18-27

Ebstein W., Die Medizin im Neuen Testament und im Talmud. Stuttgart, F. Enke, 1903

Fischer K.D., Zur Entwicklung des Ärztlichen Standes im römischen Kaiserreich. Med. Hist. J., Bd. 14, Heft 3, 1979, pp. 165-175

Herford R.T., Talmud and Apocrypha. London, Soncino Press, 1933

Jellinek A., Beth Ha-Midrasch (Sammlung). Jerusalem, Bamberger \& Wahrmann, 1938 (2nd ed.) Hebr.

Jones A.H.M., The Herods of Judaea. Oxford, Clarendon Press, 1938

Leibowitz J. O., Medical Items in the Book 'Torat Haadam' by R. Moses ben Nahman. Koroth, Vol. 8, 8-9, 1983 (pp. 257-264)

Michel O. und Bauernfeind O. (eds.), Josephus Flavius, De Bello Judaico, Der Jüdische Krieg. München (Kösel), 1962

Muntner S., The disease of Herodes the first. An answer to Dr. A.Schalit. Koroth, (1953), Vol. 1, No 3-4, pp. 134-136

Neuburger M., Die Medizin im Flavius Josephus. Bad Reichenhall, «Buchkunst», 1919, 74 pp.

Nutton V., Medicine and the Roman Army. Med. History, 13: 260-270, 1969

Plaut R., Flavius Josephus und die Bibel. Eine kritische exegetische Studie. Dissert. Univers. Leipzig/Berlin, 1867

Preuss J., Der Arzt in Bibel und Talmud. Virchows Arch. (1894), 128: 261-283

- Biblisch-Talmudische Medizin. Berlin (Karger), 1911

- Biblical and talmudic Medicine, transl. F. Rosner, New York (Sanhedrin Press), 1978

Reggio I., Letter No 3 (citing a paper by A.Jagel), Kerem Hemed, Part 2, Vienna 1836, pp. 41-50 (Hebrew)

Rengstorf K.H., A complete concordance to Flavius Josephus. Leiden, Brill, 1973 (3 vols. + index)

Scarborough J., Roman medicine and the Legions. Med. History, 12: 254-261, 1968

Schalit A., König Herodes, der Mann und sein Werk. Berlin (W. de Gruyter \& Co.), 1969 [see pp. 637-644: letter of Prof. J. O. Leibowitz cited in note 25]

Schreckenberg H., Rezeptionsgeschichtliche und textkritische Untersuchungen zu Flavius Josephus. Leiden, Brill. 1977; [see: Heilungserzählungen und das Thema der 'Vindicta Salvatoris', pp. 53-68] 


\section{Zusammenfassung}

Die Schriften des jüdischen Historikers Flavius Josephus sind eine der wichtigsten Quellen für die Kenntnis des hebräischen Altertums, auch für die Medizingeschichte dieser Zeit. Der Artikel gibt eine sorgfältige Analyse aller Stellen, wo Ärzte, Hebammen, Einbalsamierer usw. und ihre Tätigkeit erwähnt sind, und vergleicht sie mit den entsprechenden Zitaten aus dem Alten Testament, dem Talmud und dem Midrasch.

Samuel S. Kottek, M. D.

Division of History of Medicine

Hebrew University - Hadassah Medical School

Jerusalem, 91120 Israel 